\title{
Thinking and Practice of Physical Education Curriculum Construction of Preschool Education Specialty in Higher Vocational College
}

\author{
Guo yangyang \\ Shangluo Vocational \& Technical College, shangluo,shaanxi, 726000, China
}

\begin{abstract}
The major of preschool education in higher vocational education is a high-quality applied professional talents with certain cultural foundation, good professional ethics, advanced preschool education idea, systematic theoretical knowledge of preschool education specialty and solid preschool education specialty.Students majoring in preschool education in higher vocational education should learn the contents and methods of children's physical education teaching in accordance with the new situation and new trends of children's physical education teaching, so the physical education curriculum of higher vocational preschool education specialty should open the pace of overall optimization.
\end{abstract}

Keywords: vocational pre-school education major; physical education curriculum; construction path; thinking and practice

Under the background of the new curriculum reform and quality teaching concept, the physical education of young children promotes the development of children's physical and mental health and coordination ability.The major of preschool education in higher vocational education is determined to train the professionals needed for early childhood education for the society. Therefore, in carrying out the physical education teaching of pre-school education in higher vocational education, the students of preschool education in higher vocational education should pay attention to the preschool education.At

https://doi.org/10.47852/bonviewCETR2020010206

This is an open access article published by the BON VIEW PUBLISHING PTE. under the Creative Commons Attributions License. 
present, most of the kindergarten physical education work is part-time by teachers from other preschool education majors. Therefore, the preschool education specialty of higher vocational education must integrate the contents of physical education teaching which can meet the needs of children's physical education teaching, so that higher vocational students can enrich their theoretical knowledge and practical experience in physical education teaching.

\section{I.The Construction Foundation of Physical Education Curriculum for Preschool Education Specialty in Higher Vocational College}

A. The Construction of Physical Education Curriculum System of Pre-school Education Specialty in Higher Vocational College

The content design of PE course in pre-school education in higher vocational colleges must take the improvement of students' physical and psychological qualities as the basic starting point. In higher vocational pre-school education major physical education classroom to carry out a lot of higher vocational students really interested in sports.In order to fully mobilize the passion of higher vocational students to participate in sports activities, so that higher vocational students can better grasp the basic sports fitness knowledge and sports professional skills, On the basis of promoting the overall improvement of higher vocational students' physical quality, we can cultivate the good sports habits of higher vocational students' lifelong sports, and then achieve the goal of promoting the all-round and healthy development of higher vocational students ${ }^{[1]}$.

B. The Construction of Physical Education Classroom System of Pre-school Education Specialty in Higher Vocational Education

The teaching aim of preschool education major in higher vocational education is to train fulltime talents with professional accomplishment to join preschool education system such as kindergarten after entering the society. Therefore, the physical education teaching of higher vocational preschool education should be different from the teaching content of other majors with the main purpose of physical exercise.In the design and selection of teaching courses, PE courses of preschool education in higher vocational colleges should focus on cultivating students' basic ability of grasping children's physical education teaching, and promoting the all-round development of vocational students' professional skills on the basis of improving their physical education skills.

C. The Construction of Physical Education Curriculum System of Pre-school Education Specialty in Higher Vocational Education Based on Cultivating Students' Innovative Thinking and Ability.

We should pay attention to the innovation ability of higher vocational students in the physical education curriculum design of preschool education major in higher vocational education, and cultivate the innovative thinking and consciousness of higher vocational students through self-created sports items suitable for young children in the teaching process of physical education curriculum. To encourage 
higher vocational students to carry out self-study and exchange study in physical education teaching, so as to improve their ability of innovation and self-education and development ${ }^{[2]}$.

\section{Students of preschool education in higher vocational colleges must learn physical education skills in physical education}

A. It is necessary to grasp the basic sports actions suitable for children's physical education

a. Walking, running, jumping, climbing and so on are the basic movements of children's physical education. Through this simple physical exercise, children can promote the healthy development of children's body and psychology on the basis of ensuring the safety of children.

b. Simple children's gymnastics, formation queue change is the main content of children's physical education teaching course, children can improve their physical coordination ability, physical control ability and thinking ability through such simple sports.

c. National sports with local and national characteristics and simple ball games loved by children also occupy a certain position in children's physical education teaching. Traditional national sports can meet the requirements of children's personality development. Ball sports can cultivate children's team spirit and team consciousness.

B. Must be able to organize young children to participate in sports

The main sports that children can participate in include: simple children's gymnastics, simple outdoor sports games such as traditional losing handkerchief, hawk catching chicken and so on, small competitive sports activities such as shooting ball competition.

C. Must be able to innovate young children's sports

The innovation of children's sports activities mainly includes: compiling simple gymnastics for children, compiling simple sports Mini Game on their own, adapting sports equipment to children's transformation and innovation, etc.

\section{The Content of the Construction of Physical Education Curriculum System for Preschool Education Specialty in Higher Vocational College}

A. To clarify the teaching purpose of physical education curriculum for pre-school students in higher vocational education

In order to construct the physical education curriculum system of pre-school education major in higher vocational education, the aim of physical education course teaching should be clarified:To teach and explain the theoretical knowledge of PE course teaching to students of pre-school education major in higher vocational education, to teach the teaching methods of PE course, to strengthen the cultivation of students' psychological quality while improving students' physical quality, to carry out teaching suitable for the contents and methods of PE teaching for young children, to cultivate students' ability to 
organize and implement PE teaching for young children and to innovate the content of PE teaching for young children ${ }^{[3]}$.

B. Accurately setting up the contents of physical education courses for preschool education majors in higher vocational colleges

Most of the courses of preschool education in higher vocational colleges are related to preschool education, including the guidance of children's physiology and psychology, routine music and physical education courses. At present, due to the vague orientation of preschool teachers' profession, most of them pay attention to music and art courses that can sing and draw, but ignore physical education courses. Under the environment of the reform of education system in our country, the curriculum of preschool education major in higher vocational education is also being adjusted accordingly, and the orientation of physical education curriculum is gradually accurate, that is, it is necessary to adjust the teaching content of physical education curriculum to improve the relationship with other courses of preschool specialty and to improve the position of physical education curriculum in preschool specialty curriculum based on the development, cultivation and actual demand of preschool teachers ${ }^{[4]}$. The teaching content of physical education course of preschool education in higher vocational education is divided into three main aspects on the basis of the physical education ability that preschool physical education teachers need to possess.

a. Exercise in good health. The main purpose of physical education course in preschool education is to strengthen students' physique, and the teaching content of physical education course can choose the length to exercise students' explosive power and endurance;Long jump, high jump to exercise the strength of the waist and abdomen and lower limbs; sandbag, solid ball to exercise the flexibility of the hands and the strength of the upper limbs, through the teaching of physical education courses to cultivate students' awareness of long-term physical exercise, in sports constantly improve their physical fitness and the ability to adapt to changes in the natural environment.

b. Adapt to the cultivation of children's physical education teaching ability. The major of preschool education in higher vocational education is to train the professional teachers of preschool education institutions such as kindergartens for the society, and is the main person in charge of improving the physical quality of young children. Therefore, we should be familiar with and master the organization and implementation of sports activities suitable for young children.According to the physical characteristics of young children to choose sports in line with the actual needs of physical education, including: simple basketball, table tennis and other ball games;Simple children's gymnastics; simple gyro, sandbag and other folk sports; simple martial arts and other traditional sports activities; formation queue and command.Create simple sports games; sports equipment suitable for young children transformation; simple sports small competition activities and so on.

c. Carry out practical activities for children's physical education teaching.The situation design of 
children's physical education teaching can be carried out in the physical education course of preschool education major in higher vocational education.Innovative transformation of sports equipment to suit the use of young children.

C. To select the teaching methods and methods of physical education courses for preschool education in higher vocational colleges accurately

With the rapid development of the new social economy and the improvement of people's material living standard, the requirements and standards of the society and parents for the quality and ability of the staff engaged in preschool education are also improving day by day.Therefore, the teaching methods and methods of preschool education in higher vocational colleges should be reformed and optimized, and new teaching methods and methods should be actively excavated and innovated, as should physical education curriculum teaching.On the one hand, the goal of physical education teaching in preschool education in higher vocational colleges is not only to improve students' physical quality and strengthen their physique, but also to meet the actual needs of preschool teachers in the futureIn the actual teaching of physical education curriculum, we should abandon the physical education teaching with strong competitive and strong sports skills, and design the physical education teaching can participate $\mathrm{in}^{[4]}$. On the other hand, in the physical education course teaching, the competition competition competition, the independent compilation game, the simulation child physical education teaching and so on, in order to let the student participate in the physical education course enthusiastically, achieves the student to master the physical education theory knowledge skillfully and uses the physical education knowledge flexibly in the practice.

D. Accurately establish the evaluation mechanism of PE course teaching in pre-school education

The traditional teaching method of physical education course teaching in preschool education in higher vocational education is not conducive to improving the effectiveness of students' employment, so it is necessary to change the traditional single teaching evaluation method based on achievement. We should carry out the establishment of multiple teaching evaluation system.According to the characteristics of preschool education major in higher vocational education, scientific and reasonable physical education teaching goal and teaching content, the evaluation system of physical education curriculum of preschool education major in higher vocational education can be divided into four parts: theoretical evaluation, physical accomplishment evaluation, professional skill evaluation and teaching practice evaluation. The quantitative evaluation method is used in the evaluation of theory and physical accomplishment, in which the evaluation of physical accomplishment is the main aspect; the evaluation method of combining quantitative and qualitative evaluation is used in the evaluation of professional skills; and the qualitative evaluation method is used in the teaching practice ${ }^{[6]}$.

\section{Conclusion}


In the physical education curriculum design of preschool education major in higher vocational education, we should consider not only the physical fitness of higher vocational students, but also the characteristics of early childhood teaching.Therefore, in the physical education classroom, we should not only carry out the students' physical exercise, but also interspersed with the cultivation of children's physical education teaching ability, so that students can master the characteristics of children's physical education teaching while strengthening their own physique. Through various ways to improve their ability to organize and implement children's physical education teaching activities, in physical education curriculum teaching through the compilation of gymnastics, small games, sports equipment and other suitable for children to cultivate their own innovative ability, so as to promote the future career development of higher vocational students, improve the social adaptability of higher vocational students, and lay a solid foundation for the sustainable development of children's teaching work in the future.

\section{Acknowledgement}

This work is supported in part by Practical Study on the Construction of Physical Education Curriculum System of Pre-school Major in Higher Vocational Education under the Concept of "the Harmony of Curriculum and Major"Case study of Shangluo Vocational and Technical College, No.JXKT2019021

\section{References}

[1] Wang Yuyu. Discussion and Practice on Vocal Music Teaching in Preschool Education Specialty of Higher Vocational College [J].].1 Popular Literature and Art ,2019,(4):205-205.

[2] Zhou Congyin. Practice and Reflections on Fine Arts Teaching in Preschool Education Specialty of Higher Vocational College [J].].1 Shenzhou (last ten days),2019,(5):199-199.

[3] Nie Hongxia, Zhang Jing. Practice and Reflections on Fine Arts Teaching in Preschool Education Specialty of Higher Vocational College [J].].1 Hebei pictorial ,2019,(12 X):132-133.

[4] Chen Caiping, Dong Hui. A Study on the Content of Sports Game Course for Preschool Education Specialty in Higher Vocational Colleges Contemporary Sports Science and Technology ,2020,10(3):141 143.

[5] Zhang Wanjing. Practice and Reflections on Fine Arts Teaching in Preschool Education Specialty of Higher Vocational College [J].].1 Artist ,2019,(7):80-80.

[6] Liu Honghong, Zhang Yu. A Reflections on the Teaching Practice of Fine Arts Curriculum in Preschool Education Specialty [J]. Art Grand View ,2018,(5):154-154.a 